\title{
Loan Loss Provision, Good Corporate Governance Dan Manajemen Laba Bank di Indonesia dan Malaysia
}

\author{
Nurshadrina Kartika Sari, dan Nanda Widaninggar
}

STIE Mandala Jember

Jl. Sumatera No. 118-120, Jember, 68121, Indonesia

\section{Article Info}

Keywords:

Banking Sektor; Earning Management; Good Corporate Governance; and Loan Loss Provision

ISSN (print) : 2598-7763

ISSN (online): 2598-7771

$\triangle$ Corresponding Author: Nurshadrina Kartika Sari: Tel. /Fax. +6285235089814 E-mail:

shadrina.kartika@stie-mandala.ac.id (cc) BY-NC-SA

\begin{abstract}
Abtract
The development of the banking sector in Indonesia and Malaysia is growing rapidly, fierce business competition encourages management's desire to improve performance and comply with banking regulations with earnings management reported by banks. The aimed of this study provides empirical evidence of the influence of Loan Loss Provision (LLP) and Good Corporate Governance (GCG) on Earnings Management in banks in Indonesia and Malaysia. The research method used is multiple linear regression analysis using a sample of six banks with the largest assets in each country during the 2015-2018 periods. The results of this study prove that (1) LLP and GCG affect earnings management at banks in Indonesia (2) LLP has no effect on earnings management at banks in Malaysia, while GCG affects earnings management at banks in Malaysia. The application of financial accounting standards IFRS 7 on financial instruments requires provision for impairment losses early so as to reduce the need for management in managing earnings; this further strengthens the need for PSAK 71 to be implemented in the banking sector in Indonesia effectively from 2020. In addition, the GCG mechanism in both countries also went well so as to be able to influence the practice of earnings management in banks
\end{abstract}

Citation: Sari, N.K., dan Widaninggar, N. (2020). Loan Loss Provision, Good Corporate Governance Dan Manajemen Laba Bank di Indonesia dan Malaysia . AFRE Accounting and Financial Review, 3 (1)

\begin{abstract}
Abstraks
Perkembangan sektor perbankan di Indonesia dan Malaysia bertumbuh pesat, persaingan bisnis yang ketat mendorong keinginan manajemen meningkatkan kinerja dan mematuhi peraturan perbankan dengan pengelolaan laba yang dilaporkan bank. Tujuan penelitian untuk menganalisis pengaruh Loan Loss Provision (LLP) dan Good Corporate Governance (GCG) terhadap Manajemen Laba pada bank di Indonesia dan Malaysia. Metode penelitian yang digunakan adalah analisis regresi linier berganda dengan menggunakan sampel enam bank dengan aset terbesar di masing-masing negara selama periode 2015-2018. Hasil penelitian ini membuktikan bahwa (1) LLP dan GCG berpengaruh terhadap manajemen laba pada bank di Indonesia (2) LLP tidak berpengaruh terhadap manajemen laba pada bank di Malaysia, sedangkan GCG berpengaruh terhadap mamajemen laba pada bank di Malaysia. Penerapan standar akuntansi keuangan yaitu IFRS 7 tentang instrumen keuangan mensyaratkan pencadangan kerugian penurunan nilai lebih awal sehingga mampu mengurangi kebutuhan manajemen dalam melakukan manajemen laba, hal ini semakin menguatkan kebutuhan pengimplementasian PSAK 71 pada sektor perbankan di Indonesia yang efektif mulai tahun 2020. Selain itu mekanisme GCG di kedua negara juga berjalan baik sehingga mampu mempengaruhi praktik manajemen laba di bank.
\end{abstract}

JEL Classification: G21, G32, G34

DOI: http://doi.org/10.26905/afr.v3i1.4555

\section{PENDAHULUAN}

Laporan keuangan merupakan suatu pen- yajian terstruktur dari posisi keuangan dan kinerja keruangan suatu entitas (IAI, 2015). Laporan keuangan juga merupakan bentuk per- 


\section{Loan Loss Provision, Good Corporate Governance Dan Manajemen Laba Bank di Indonesia dan Malaysia Nurshadrina Kartika Sari, dan Nanda Widaninggar}

tanggungjawaban manajemen kepada pemegang saham dan pihak eksternal yang memberikan informasi terkait perkembangan entitas dalam kegiatan usahanya (Puspita, 2019). Dalam perkembangannya laporan keuangan yang dihasilkan akuntansi tidak hanya memberikan informasi yang bersifat keuangan namun juga nonkeuangan.

Laporan keuangan juga menjadi sinyal yang diberikan perusahaan kepada penggunanya tentang kondisi keuangan perusahaan (Smith \& Pennathur, 2019), (Siladjaja \& Anwar, 2019), (Kharouf, Lund, Krallman, \& Pullig, 2020) dan (Arifin, 2020). Sehingga laporan keuangan harus netral, lengkap, mempunyai daya banding dan uji. Manajemen sebagai pemilik informasi tentang perusahaan dianggap memiliki kesempatan untuk mengatur, mengelola bahkan menyembunyikan in-formasi yang dimilikinya terkait dengan kinerja perusahaan. Fenomena ini telah banyak diteliti dan menjadi perhatian publik untuk mendorong perwujudan tata kelola perusahaan yang baik, fenomena ini dikenal dengan manajemen laba.

Praktik manajemen laba dilakukan untuk mempengaruhi laba yang dilaporkan dengan motif-motif tertentu (Weerathunga, Xiaofang, \& Sameera, 2020; García Lara, García Osma, \& Penalva, 2020, dan (Li, Li, Xiang, \& Djajadikerta, 2020). Terdapat 31 bank di Indonesia melakukan manajemen laba dengan faktor-faktor yang mempengaruhi manajemen laba tersebut adalah kepemilikan institusional, kepemilikan manajemen, ukuran bank dan CAR (Sari dan Astuti, 2015). Untuk menekan praktik tersebut yaitu melalui penerapan Standar Akuntansi Keuangan yang sudah mengadopsi International Financial Reporting Standard (IFRS). Berdasarkan hasil penelitian (Sari, Turdjono dan Widaninggar, 2017) praktik manajemen laba pada Bank Pemerintahan di Indonesia mengalami penurunan setelah adanya penerapan IFRS.

Dorongan kebutuhan untuk menghasilkan informasi tentang kondisi perusahaan yang relevan dan akuntabel, diberikan oleh pemberi wewenang (principal) kepada manajemen (agent) sehingga menyebabkan perbedaan kepentingan diantara kedua-nya. Bank dituntut dituntut mencapai kinerja yang baik melalui pencapaian laba. Bank sebagai lembaga intermediasi secara tradisonal masih me-ngandalkan pendapatan dari bunga kredit (Haryanto, Bachtiar, \& Khotami, 2020). Bank dituntut untuk efisien dalam operasionalnya (Demirgüç-Kunt \& Huizinga, 1999;
Al-deehani, El-Sadi, \& Al Deehani, 2015; Sari \& Widaninggar, 2018; Haryanto, 2018; (Rusydiana \& Laila, 2019).

Salah satu mekanisme manajemen laba yang digunakan pada sektor perbankan adalah penggunaan Loan Loss Provision (LLP) atau dikenal dengan Cadangan Kerugian Penurunan Nilai (CKPN). Beberapa penelitian yang menemukan bukti bahwa LLP menjadi alat mekanisme manajemen laba di bank diantaranya disampaikan oleh Ruey, Wen dan Chung (2008), Curcio dan Hasan (2008), Ooserbosh (2009), Dong, Liu dan $\mathrm{Hu}$ (2012), Abdullah, Bujang dan Ahmad (2015), Habib, Hasan, Mollah, \& Molyneux (2020), dan Salem, Usman, \& Ezeani (2020).

Tata Kelola perusahaan diperlukan dalam upaya memberikan rasa aman investor. Investor akan memperoleh informasi perusahaan yang benar tentang perusahaan. Efektifitas pengawasan yang dilakukan oleh komisaris independent dapat mengurangi terjadinya menajamen laba. Kinerja perusahaan diyakini akan meningkat ketika perusahan menerapkan tata kelola perusahaan (Leuz, Nanda, \& Wysocki, 2003), (Huson, Malatesta, \& Parrino, 2004), (Putri, Haryanto, \& Firdaus, 2018), (Al Farooque, Buachoom, \& Sun, 2020) dan (Al-ahdal, Alsamhi, Tabash, \& Farhan, 2020).

Berdasarkan penelitian terdahulu yang dilakukan oleh Abed, Al-Attar dan Suwaidan (2012) membuktikan bahwa mekanisme Good Corporate Governance (GCG) memiliki pengaruh signifikan terhadap manajemen laba pada perusahaan non keuangan di Jornadia periode 20062009. Selanjutnya Swastika (2013) membuktikan bahwa GCG yang diukur dengan dewan direksi dan kualitas audit berpengaruh terhadap manajemen laba yang diukur dengan discretionary accruals.

Tujuan penelitian untuk menganalisis pengaruh Loan Loss Provision (LLP) dan Good Corporate Governance (GCG) terhadap Manajemen Laba pada bank di Indonesia dan Malaysia.

\section{PENGEMBANGAN HIPOTESIS}

Teori agensi menjelaskan mengenai hubungan yang terjadi antara pemilik dan pemegang saham sebagai principal dengan manajer sebagai agent muncul pertama kali pada tahun 1976 oleh Jensen dan Meckling. Pihak principal memberikan kewenangan dan kepercayaannya kepada agent untuk mengelola perusahaan. Pemilik ataupun pe-megang saham mengi- 
nginkan manajer yang menja-lankan perusahaan bekerja sesuai dengan apa yang diharapkan oleh mereka, selain itu manajer juga dituntut untuk mampu menghasilkan profit bagi pemilik dan pemegang saham.

Adanya teori agensi tersebut ditambah dengan adanya ketidakseimbangan informasi (asimetris informasi) yang dimiliki manajer sebagai agent kemudian menunculkan kesempatan untuk mengatur laba yang dilaporkan dalam laporan keuangan. Informasi berlebih yang dimiliki manajer dikelola untuk bisa memberikan sinyal positif tentang keadaan perusaan kepada pihak eksternal perusahaan, termasuk kepada pemegang saham.

Perusahaan melalui manajer menyusun laporan keuangan bagi pihak eksternal, melalui kendali yang dimiliki manajer, mereka berpeluang menggunakan intervensinya dalam penyusunan laporan keuangan demi tujuan tertentu yang dapat menguntungkan mereka. Praktik pengelolaan laba tersebut dikenal dengan Manajemen Laba. Pada sektor perbankan manajemen laba tidak hanya digunakan untuk meningkatkan performa manajemen namun juga dalam rangka mematuhi peraturan perbankan, seperti menjaga rasio permodalan dan rasio kredit macet. Sulistyanto (2014) menambahkan bahwa perilaku manajemen dalam mere-kayasa proses penyusunan laporan keuangan me-rupakan dianggap bukan kecurangan karena masih dalam koridor standar akuntansi dan prosedur akuntansi yang diterima dan berlaku umum.

Pengelolaan akun akrual yang dilakukan dalam praktik manajemen laba diantaranya melalui pencadangan kerugian penurunan nilai/ Loan Loss Provision. Pada sektor perbankan risiko kredit atas macetnya kredit yang disalurkan dapat dicadangkan apabila terdapat bukti objektif penurunan nilai pinjaman, pencadangan ini akan mengurangi laba yang dilaporkan bank. Pembentukan LLP sebagai penurunan nilai aset akan menjadi pengurang laba akuntasi, sehingga dapat digunakan sebagai tindakan manajer dalam mempengaruhi pelaporan laba yang seharusnya dilaporkan. Pola rekayasa yang dilakukan manajer tergantung pada motif yang ingin dicapainya, salah satunya bank harus mematuhi aturan terkait dengan permodalan/CAR dan tingkat rasio kredit macet/ NPL.

Dong, Liu dan Hu (2012) menemukan bahwa Loan Loss Provision (LLP) merupakan alat yang digunakan bank komersial di China dalam melakukan income smoothing dan memiliki hubungan negatif antara LLP dengan CAR bank. Sedangkan Oosterbosch (2009) membuktikan bahwa pengung-kapan dalam LLP setelah diberlakukannya IFRS tidak menghalangi manajer bank menggunakan LLP sebagai kebijakan mereka dalam perataan laba.

Mekanisme Good Corporate Governance (GCG) merupakan tata kelola perusahaan yang mampu melindungi stakeholder dan kreditor dari kecu-rangan-kecurangan yang timbul dalam dunia bis-nis. Empat prinsip GCG adalah keadilan, transparasi, akuntabilitas dan responsibilitas. Keempat prinsip tersebut akan mengarahkan perusahaan pada pelaksanaan tata kelola yang bersih dan bertanggungjawab.

Tuntutan pelaksanaan kegiatan bisnis yang bersih, sehat dan bertanggungjawab sangat diha-rapkan dapat terwujud, karena kegiatan bisnis yang tidak sehat dapat menyebabkan kerugian bagi berbagai pihak termasuk perekonomian di suatu negara. Mekanisme GCG diharapkan dapat mene-kan tindakan tidak sehat dari kultur perusahaan yang dibangun secara keliru, termasuk adanya praktik manajemen laba di perusahaan.

Sutikno dkk. (2014) menggunakan 120 bank yang terdaftar di BEI selama kurun waktu 2008 hingga 2012 dan menemukan bahwa Corporate Governance dengan menggunakan kepemilikan institusional dan ukuran perusahaan berpengaruh terhadap manajemen laba. Sedangkan Chtourou dkk. (2001) dewan komisari dan komite audit dapat me-nekan aktivitas manajemen laba pada perusahaan di Amerika Serikat.

Hipotesis yang diajukan pada penelitian ini adalah sebagai berikut:

$\mathrm{H}_{1 \mathrm{a}}$ : Loan Loss Provision (LLP) berpengaruh terhadap manajemen laba pada bank di Indonesia

$\mathrm{H}_{1 \mathrm{~b}}$ : Loan Loss Provision (LLP) berpengaruh terhadap manajemen laba pada bank di Malaysia

$\mathrm{H}_{2 \mathrm{a}}$ : Good Corporate Governance (GCG) berpengaruh terhadap manajemen laba pada bank di Indonesia

$\mathrm{H}_{2 b}$ : Good Corporate Governance (GCG) berpengaruh terhadap manajemen laba pada bank di Malaysia

\section{DATA DAN METODE}

Jenis dan sumber data yang digunakan pada penelitian ini adalah data sekunder berupa 


\section{Loan Loss Provision, Good Corporate Governance Dan Manajemen Laba Bank di Indonesia dan Malaysia Nurshadrina Kartika Sari, dan Nanda Widaninggar}

laporan keuangan tahunan yang dipublikasikan oleh bank di Indonesia dan Malaysia selama periode 2015 hingga 2018. Sedangkan populasi penelitian adalah bank di Indonesia dan Malaysia dan dipilih meng-gunakan purposive sampling yaitu enam bank dengan nilai total aset tertinggi di Indonesia dan Malaysia selama periode 2015-2018.

Teknik analisis data menggunakan regresi linier berganda yaitu untuk mengetahui pengaruh LLP dan GCG terhadap Manajemen Laba (EM) pada bank di Indonesia dan di Malaysia. Persamaan regresi yang digunakan adalah sebagai berikut:

$$
\begin{aligned}
& \mathrm{EM}_{\text {Ind }}=\alpha+\beta_{1} L L P_{\text {Ind }}+\beta_{2} G C G_{\text {Ind }}+e \\
& \mathrm{EM}_{M l y}=\alpha+\beta_{1} L L P_{\text {Mly }}+\beta_{2} G C G_{\text {Mly }}+e
\end{aligned}
$$

Dimana: $\mathrm{EM}_{\text {Ind }}=$ Earning Management/Manajemen Laba pada Bank di Indonesia, $\mathrm{EM}_{\mathrm{Mly}}=$ Earning Management/Manajemen Laba pada Bank di Malaysia, $a=$ Konstanta, $b_{1}, b_{2}=$ Koefisien regresi variabel LLP, GCG, LLP Ind $_{\text {In }}$ Loan Loss Provision pada Bank di Indonesia, $\mathrm{LLP}_{\mathrm{Mly}}=$ Loan Loss Provision pada Bank di Malaysia, $\mathrm{GCG}_{\text {Ind }}=$ Good Corporate Governance pada Bank di Indonesia, $\mathrm{GCG}_{\mathrm{Mly}}=$ Good Corporate Governance pada Bank di Malaysia dan e $=$ variabel residual

Pengukuran masing-masing variabel peneliti-an adalah sebagai berikut:

Loan Loss Provision mengacu dari Abdullah, dkk., (2013):

\section{LLP $=$ Total LLP/Total Asset}

GCG diukur dengan dengan menggunakan Corporate Governance Perception Index (CGPI) ada 38 item yang digunakan dalam pengungkapan GCG dimana masing-masing skor sub-indeks diberi angka 1 untuk diungkapkan dan 0 untuk tidak diungkapkan. Adapun rumus CGPI adalah sebagai berikut:

$$
\mathrm{CGI}=\frac{\mathrm{A}+\mathrm{B}+\mathrm{C}+\mathrm{D}+\mathrm{E}}{\text { Total Item }} \times 100 \%
$$

Dimana: CGI = Corporate Governance Index, A= Hak pemegang saham, $\mathrm{B}=$ Dewan direktur, $\mathrm{C}=$ Dewan komi-saris, $\mathrm{D}=$ Komite audit dan auditor internal, $\mathrm{E}=$ Pe-ngungkapan terhadap investor.

Manajemen Laba dihitung dengan menggunakan discretionary accruals dan dihitung menggunakan The Modified Jones Model dengan langkah-langkah sebagai berikut:

$$
\mathrm{TA}_{\mathrm{i}, \mathrm{t}}=\mathrm{N}_{\mathrm{i}, \mathrm{t}}-\mathrm{CFO}_{\mathrm{i}, \mathrm{t}}
$$

Nilai $\mathrm{TA}_{\mathrm{i}, \mathrm{t}}$ diestimasi dengan persamaan regresi berganda, yaitu:

$$
\begin{aligned}
& \mathrm{TA}_{\mathrm{i}, \mathrm{t}} / \mathrm{TA}_{\mathrm{i}, \mathrm{t}-1}=\alpha_{1}\left(1 / \mathrm{AT}_{1, t-1}\right)+\alpha_{2}\left(\Delta \mathrm{REV}_{\mathrm{i}, \mathrm{t}} / \mathrm{AT}_{\mathrm{i}, \mathrm{t}-1}\right)+\alpha_{3}\left(\mathrm{PPE}_{\mathrm{i}, \mathrm{t}}\right)+\mathrm{e} \\
& \mathrm{NDA}=\alpha_{1}\left(1 / \mathrm{AT}_{\mathrm{i}, \mathrm{t}-1}\right)+\alpha_{2}\left\{\left(\Delta \mathrm{ARV}_{\mathrm{i},-1} / \Delta \mathrm{REC}_{\mathrm{i}, \mathrm{t}}\right) / \mathrm{AT}_{\mathrm{i}, \mathrm{t}-1}\right\}+\alpha_{3}\left(\mathrm{PPE}_{\mathrm{it}} / \mathrm{AT}_{\mathrm{i}, \mathrm{t}-1}\right) \\
& \mathrm{DAC} \mathrm{C}_{\mathrm{i}, \mathrm{t}}=\mathrm{TA}_{\mathrm{i}, \mathrm{t}} / \mathrm{AT}_{\mathrm{i}, \mathrm{t}-1-1}-\mathrm{NDA}
\end{aligned}
$$

Dimana: $\mathrm{DAC}_{\mathrm{it}}=$ discretionary accruals bank i pada periode $\mathrm{t}, \mathrm{TACC}_{\mathrm{it}}=$ total accruals bank $\mathrm{i}$ pada periode $\mathrm{t}$, $\mathrm{CFO}_{\mathrm{it}}=$ cash flow operating bank $\mathrm{i}$ pada periode $\mathrm{t}, \mathrm{TA}_{\mathrm{i}, \mathrm{t}}=$ total accrual bank i periode $\mathrm{t}, \mathrm{AT}_{\mathrm{i}, \mathrm{t}-1}=$ total asset bank $\mathrm{i}$ periode $t_{-1}, N_{i-t}=$ laba bersih bank i periode $t, \Delta R E V_{i t}=$ perubahan pendapatan bank $i$ dalam periode $t$, $\Delta \mathrm{REC}_{\mathrm{it}}=$ perubahan pemberian kredit bank $\mathrm{i}$ dalam periode $t, \mathrm{PPE}_{\mathrm{it}}=$ nilai aktiva tetap (gross) bank i pada periode $t, \mathrm{NDA}=$ non discretionary accrual, $\alpha 1, \alpha 2, \alpha 3$ : koefisien regresi dan $\mathrm{e}=$ error

Berrdasarkan hasil uji asumsi klasik menunjukkan data bebas dari multikolinieritas, autokorelasi dan heteroskedastisitas. Sehingga dapat dilakukan analisis data.

\section{HASIL}

Sampel pada penelitian ini terdiri dari enam bank yaitu bank BRI, bank Mandiri, bank BCA untuk bank yang ada di Indonesia dan bank Maybank, bank CIMB dan Public Bank Berhad untuk bank yang ada di Malaysia. Keenam bank tersebut merupakan bank dengan total aset terbesar selama periode 2015-2018.

Berdasarkan hasil pengujian asumsi klasik menunjukkan tidak terjadi multikolineritas, autokorelasi dan heteroskedasitas. Data yang digunakan berdistribusi normal. Sehingga data memenuhi asumsi klasik.

Berdasarkan tabel 1 menunjukkan rata-rata earning manajemen bank di Indonesia lebih tinggi dibandingkan Malaysia sebesar. Demikian juga dengan LLP dan GCG Indonesia lebih tinggi dibandingkan dengan Malaysia (Tabel 1).

Tabel 1. Deskripsi Data

\begin{tabular}{lrrrrrrrr}
\hline & \multicolumn{2}{c}{ Minimum } & \multicolumn{2}{c}{ Maksimum } & \multicolumn{2}{c}{ Rata-Rata } & \multicolumn{2}{c}{ Std. Deviation } \\
& Indonesia & \multicolumn{1}{c}{ Malaysia } & \multicolumn{1}{c}{ Indonesia } & Malaysia & Indonesia & Malaysia & Indonesia & Malaysia \\
\hline EM & $-51,26$ & $-109,72$ & 14,77 & $-5,77$ & $-12,5471$ & $-58,9901$ & 29,19921 & 42,35187 \\
LLP & 0,02 & 0,00 & 0,03 & 0,01 & 0,0245 & 0,0023 & 0,00562 & 0,00201 \\
GCG & 0,50 & 0,26 & 0,66 & 0,58 & 0,6053 & 0,3947 & 0,06146 & 0,12241 \\
\hline
\end{tabular}

Catatan: EM= Earning Manajement, LLP=Loan Loss Provision, GCG= Good Corporate Governance. 
Tabel 2. Hasil Regresi

\begin{tabular}{lrr}
\hline Variabel & \multicolumn{1}{c}{$\begin{array}{c}\text { Model 1 } \\
\text { (Indonesia) }\end{array}$} & \multicolumn{1}{c}{$\begin{array}{c}\text { Model 2 } \\
\text { (Malaysia) }\end{array}$} \\
\hline Konstanta & $-187,132$ & $-179,748$ \\
LLP & $-1.158,258$ & $-1.424,395$ \\
& $(0,001)$ & $(0,608)$ \\
GCG & 33,809 & 314,211 \\
& $(0,000)$ & $(0,000)$ \\
\hline
\end{tabular}

Berdasarkan tabel 2 menunjukkan bahwa Loan Loss Provision (LLP) di Indonesia berpengaruh terhadap manajemen laba sedangkan di Bank di Malayisa tidak berpengaruh. Sedangkan untuk good corporate governance baik bank di Indonesia maupun di Malayasia berpengaruh terhadap manajemen laba.

\section{PEMBAHASAN}

\section{Loan Loss Provision Terhadap Manajemen Laba pada Bank di Indonesia dan Malaysia}

Hasil penelitian ini menunjukkan bahwa terdapat pengaruh Loan Loss Provision (LLP) terhadap Manajemen Laba pada Bank di Indonesia Sedangkan untuk Bank di Malaysia menunjukkan Loan Loss Provision (LLP) tidak berpengaruh terhadap Manajemen Laba. Pembentukan LLP sebagai penurunan nilai aset akan menjadi pengurangan laba akuntansi, penilaian penurunan kredit yang dimiliki debitur harus menggunakan bukti objektif dan penentuan cadangannya dapat berbeda pada masing-masing bank. Hal ini menjadikan adanya perbedaan pengaruh LLP pada bank di Indonesia dan di Malaysia.

Pengaplikasian LLP sebagai alat manajemen laba di bank telah dibuktikan oleh Dong, Liu dan $\mathrm{Hu}$ (2012) pada bank komersial di Cina pada periode 2001-2009. Penggunaan LLP dalam memanipulasi laba yang dilaporkan bank bertujuan menyetabilkan harga saham, pelaporan tahunan laba sebelum pajak dan meningkatkan kepercayaan investor. LLP juga digunakan manajemen bank untuk menguatkan rasio CAR Ketika mengalami penurunan dengan mencadangkan banyak LLP. Sedangkan Ruey, Wen dan Chung (2008) menemukan bahwa manajer bank menggunakan LLP pada manajemen laba untuk menurunkan rasio NPL bank yang meningkat. Pada bank di Indonesia LLP terbukti berpengaruh terhadap manajemen laba, mendukung penelitian Dong, Liu dan Hu (2012), sedangkan berkebalikan dengan hasil yang diperoleh di bank Malaysia LLP justru tidak berpengaruh terhadap manajemen laba. Hasil ini menunjukkan bahwa bank di Malaysia tidak menggunakan LLP sebagai alat manajemen laba, hasil ini tidak sesuai dengan penelitian yang dilakukan oleh Abdullah, Bujang dan Ahmad (2015) yang membuktikan bahwa bank komersial di Malaysia menggunakan pencadangan penurunan nilai asset dalam praktik manajemen laba.

Good Corporate Governance Terhadap Manajemen Laba pada Bank di Indonesia dan di Malaysia

Berdasarkan hasil analisis yang telah dilakukan diketahui bahwa GCG berpengaruh terhadap Manajemen laba pada Bank di Indonesia. Demikian juga dengan bank di Malaysia menunjukkan bahwa GCG berpengaruh terhadap Manajemen Laba. Hasil menunjukkan bahwa semakin banyak pengungkapan item GCG menunjukkan bahwa semakin tinggi indeks GCG yang menunjukkan bahwa semakin baiknya mekanisme GCG pada bank tersebut. Menurut standar akuntansi keuangan pengungkapan wajib yang harus dilaporkan perusahaan diantaranya pengungkapan laporan keuangan, catatan atas laporan keuangan dan informasi pelengkap yang diwajibkan. Laporan GCG yang disampaikan perusahaan merupakan informasi lengkap yang diwajibkan, bahkan bagi perusahaan publik di pasar modal diwajibkan untuk mengungkapkan semua pengungkapan termasuk yang disyaratkan pada standar akuntansi keuangan (Subroto, 2014). Kecenderungan yang terjadi adalah bank melaporkan pengungkapan GCG semata-mata untuk memenuhi kewajiban atas peraturan yang berlaku, sehingga praktik manajemen labapun tetap dilakukan oleh manajemen kendati mekanisme GCG terbukti baik pada bank tersebut.

Hasil penelitian ini sejalan dengan penelitian yang dilakukan oleh Abed, Al-Attar dan Suwaidan (2012) yang menggunakan ukuran dewan direksi sebagai proxy Corporate Governance dan membuktikan peran dewan direksi mampu menekan manajemen laba. Sedangkan Ugbede, Lizam dan Kaseri (2013) membuktikan bahwa GCG pada bank di Malaysia lebih mampu menekan praktik manajemen laba disbanding pada bank yang ada di Nigeria.

Loan Loss Provision dan Good Corporate Governance Terhadap Manajemen Laba pada Bank di Indonesia dan di Malaysia

Berdasarkan hasil penelitian ini dapat disimpulkan bahwa ada perbedaan pengaruh LLP dan GCG terhadap manajemen laba yang 


\section{Loan Loss Provision, Good Corporate Governance Dan Manajemen Laba Bank di Indonesia dan Malaysia Nurshadrina Kartika Sari, dan Nanda Widaninggar}

terjadi pada bank di Indonesia dan Malaysia, perbedaan tersebut khususnya adalah pada LLP yang berpengaruh terhadap manajemen laba pada bank di Indonesia namun tidak pada bank di Malaysia. Terbukti bahwa bank di Malaysia tidak mengambil kebijakan pencadangan LLP untuk melakukan income smoothing atas laba yang dilaporkannya, hal ini menunjukkan bahwa manajemen bank menggunakan pertimbangan kondisi ekonomi sebagai faktor makro ekonomi yang diperhitungkan dalam menentukan cadangan kerugian penurunan nilai. Menurut Abdul lah, Bujang dan Ahmad (2015) bank di Malaysia cenderung mencadangkan sedikit LLP pada saat kondisi ekonomi baik dan sebaliknya, ketika kondisi ekonomi baik bank berasumsi bahwa peminjam masih mampu membayar pinjamannya.

Pencadangan LLP terkait risiko kredit berasosiasi dengan pinjaman yang diberikan, sehingga semakin tinggi rasio Nonperforming Loan (NPL) yang dimiliki bank, maka bank akan mempertimbangkan untuk mencadangkan LLP lebih banyak. Pada bank di Malaysia pencadangan penurunan nilai aset dilakukan lebih awal untuk mengantisipasi risiko kredit yang dapat dihadapi atas kredit tak tertagih, sehingga rasio NPL dapat terjaga dan manajemen tidak perlu melakukan pencadangan tiba-tiba hingga mengurangi laba bank yang dilaporkan. Hal tersebut dilaksanakan sesuai dengan aturan pada standar keuangan internasional yaitu IFRS 7.

Perbankan di Indonesia mencadangkan LLP ketika pinjaman tidak tertagih mengalami peningkatan, hal ini diperbolehkan sesuai dengan PSAK 55. Dimana cadangan kerugian penurunan nilai aset dinilai dengan dengan menggunakan nilai wajar setelah ditemukan ada bukti objektif adanya penurunan nilai aset. Setelah dicadangkan ketika pada tahun berikutnya jumlah penurunan kerugian berkurang, manajemen dapat melakukan pembalikan aset keuangan diakui pada laporan laba rugi. Hal ini memungkinkan manajemen mengatur pengakuan lebih lambat ataupun lebih cepat sesuai motivasi yang melatarbelakanginya.

\section{SIMPULAN DAN SARAN}

Simpulan hasil penelitian ini adalah (1) terdapat pengaruh LLP terhadap manajemen laba pada bank di Indonesia, tetapi LLP tidak berpengaruh terhadap manajemen laba pada bank di Malaysia, (2) terdapat pengaruh GCG terjadap manajemen laba pada bank di Indonesia dan di Malaysia. Hasil penelitian ini menambah bukti bahwa mekanisme GCG berperan penting untuk menekan praktik manajemen laba baik pada bank di Indonesia dan Malaysia. Temuan lain menunjukkan bahwa penerapan standar akuntansi yang telah diimplementasikan oleh perbankan di Malaysia mampu meningkatkan kehati-hatian bank dalam kaitannya dengan risiko kredit. IFRS 7 mensyaratkan pencadangan kerugian penurunan nilai aset sedini mungkin, sehingga tidak langsung merdampak pada tergerusnya laba yang dilaporkan pada periode bersangkutan. Pelaporan laba yang menurun tentu saja memotivasi manajemen untuk melakukan praktik pengelolaan laba/ manajemen laba untuk bisa memenuhi ekspektasi performa bank yang baik, yaitu dalam kaitannya dengan rasio permodalan dan rasio risiko kredit yang harus dijaga oleh bank. Sedangkan pada perbankan di Indonesia penerapan PSAK 71 yang telah mengadopsi penuh IFRS 7 baru efektif dilaksanakan pada tahun 2020, sehingga diperlukan kesegeraan penerapan PSAK 71 untuk bisa membantu perbankan dalam mengantisipasi penurunan nilai atas aset, khususnya pada kredit yang disalurkan bank.

Keterbatasan penelitian ini adalah belum menambahkan faktor makroekonomi seperti GDP atau inflasi untuk melihat pengaruhnya terhadap praktik manajemen laba di bank. Penelitian selanjutnya dapat menambahkan faktor makroekonomi dan mengkaji dampak penerapan PSAK 71 khususnya bagi perbankan di Indonesia.

\section{UCAPAN TERIMA KASIH}

Ucapan terimakasih penulis sampaikan kepada Pusat Penelitian dan Pengabdian pada Masyarakat (PPPM) STIE Mandala Jember yang memberikan kesempatan kepada penulis untuk menyusun dan menyelesaikan penelitian ini.

\section{DAFTAR PUSTAKA}

Abdullah, H., Bujang dan Ahmad. (2015). Loan Loss Provisions and Earning Management in Malaysian Banking Industry. Global Journal of Business and Social Science Review 1 (1): 93-104.

Abed, S., Al-Attar dan Suwaidan. (2012). Corporate Governance and Earning Management: Jordania Evidence. International 
Business Research. 5 (1).

Al-ahdal, W. M., Alsamhi, M. H., Tabash, M. I., \& Farhan, N. H. S. (2020). The impact of corporate governance on financial performance of Indian and GCC listed firms: An empirical investigation. Research in International Business and Finance, 51(September 2018), 101083. https://doi.org/10.1016/j.ribaf.2019.10108 3

Al-deehani, T. M., El-Sadi, H. M., \& Al Deehani, M. T. (2015). Performance of Islamic banks and conventional banks before and during economic downturn. Investment Management and Financial Innovations, 12(2).

Al Farooque, O., Buachoom, W., \& Sun, L. (2020). Board, audit committee, ownership and financial performance - emerging trends from Thailand. Pacific Accounting Review, 32(1), 54-81. https://doi.org/10.1108/ PAR-10-2018-0079

Arifin, J. (2020). Disclosure of Financial Statements on the Website: An Empirical Study in Indonesian Local Governments. Review of Integrative Business and Economics Research, 9(2), 174-188. Retrieved from https://search.proquest.com/docview/23 67740620 ?accountid $=17242$

Curcio, D. and Hasan, I. (2008). Earnings- and Capital-Management and Signaling: The Use of Loan Loss Provisions by European Banks. Italy: University Luiss Guido Carli.

Demirgüç-Kunt, A., \& Huizinga, H. (1999). Determinants of commercial bank interest margins and profitability: Some international evidence. World Bank Economic Review, 13(2), 379-408. https://doi.org/10.1093/wber/13.2.379

Dong, X., Liu and Hu. (2012). Research on the Relationship of Commercial Bank's Loan Loss Provision and Earning Management and Capital Management. Journal of Service Science and Management. 5: 171-179.

Firdaus, M. 2019. Ekometrika Suatu Pendekatan Aplikatif. (Edisi 3). Jakarta: Bumi Aksara.

García Lara, J. M., García Osma, B., \& Penalva, F. (2020). Conditional conservatism and the limits to earnings management. Journal of Accounting and Public Policy, 39(4). https://doi.org/10.1016/j.jaccpubpol.2020 .106738

Habib, A., Hasan, M. M., Mollah, S., \& Molyneux, P. (2020). Financial Statement Comparability, Earnings Smoothing and
Loan-Loss Provisioning in Banking. SSRN Electronic Journal, (June). https://doi.org/ 10.2139/ssrn.3622974

Haryanto, S. (2018). Determinan Efisiensi Bank: Analisis Bank Di Indonesia. 1(1), 46-52. https://doi.org/26.82017/JKP.2017.001

Haryanto, S., Bachtiar, Y., \& Khotami, W. (2020). Efficiency and Rentability of Islamic Banks in Indonesia. Inovator Jurnal Manajemen, 9(1), 41-48. https://doi.org/10.1166/ asl.2017.9975

Huson, M. R., Malatesta, P. H., \& Parrino, R. (2004). Managerial succession and firm performance. Journal of Financial Economics, 74(2), 237-275. https://doi.org/10.1016/ j.jfineco.2003.08.002

Ikatan Akuntan Indonesia (IAI). 2015. Standar Akutansi Keuangan. Jakarta.

Ilmi, M., Alwan, S.K. dan Sayekti, Y. (2017). Effect of Good Corporate Governance, Corporate Social Responsibility Disclousure and Managerial Ownership to the Corporate Value with Financial Performance as Intervening Variables: Case on Indonesia Stock Exchange. International Journal of Social Science and Business. 1 (2): 75-88.

Kharouf, H., Lund, D. J., Krallman, A., \& Pullig, C. (2020). A signaling theory approach to relationship recovery. European Journal of Marketing. https://doi.org/10.1108/EJM10-2019-0751

Leuz, C., Nanda, D., \& Wysocki, P. D. (2003). Earnings management and investor protection: an international comparison \$. 69, 505-527. https://doi.org/10.1016/S0304405X(03)00121-1

Li, Y., Li, X., Xiang, E., \& Djajadikerta, H. G. (2020). Financial distress, internal control, and earnings management: Evidence from China. Journal of Contemporary Accounting and Economics, 16(3), 100210. https://doi.org/10.1016/j.jcae.2020.100210

Nugroho, B.A. (2005). Strategi Jitu Memilih Metode Statistik Penelitian dengan SPSS. Yogyakarta: Andi.

Oosterbosch, R.V. (2009). Earnings Management in the Banking Industry-The Consequences of IFRS Implementation on Disretionary Use of Loan Loss Provisions. Unpublished Thesis. Belanda: University Rotterdam.

Puspita, M. P. P. G. (2019). Tingkat Laba dan Perubahan Laba: Manakah yang Lebih Relevan? AFRE (Accounting and Financial Review), 2(2), 91-97. https://doi.org/ 


\subsection{5/afr.v2i2.3091}

Putri, E. L., Haryanto, S., \& Firdaus, R. M. (2018). Mampukah Good Corporate Governance dan Risiko Kredit Sebagai Prediktor Financial Distress? AFRE (Accounting and Financial Review), 1(1), 26-35. https://doi.org/26.82017/JKP.2017.001

Ruey, C. D, Wen and Chung. (2008). Discretionary Loan Loss Provisions and Earning Management for the Banking Industry. International Business $\mathcal{E}$ Economics Research Journal. 7(3).

Rusydiana, A. S., \& Laila, N. (2019). Efisiensi dan produktivitas industri perbankan pada sistem moneter ganda di Indonesia Pendahuluan. 23(1), 50-66. https://doi.org/10.20885/jsb.vol23.iss1.art 5

Salem, R., Usman, M., \& Ezeani, E. (2020). Loan Loss Provisions and Audit Quality: Evidence from MENA Islamic and Conventional Banks. The Quarterly Review of Economics and Finance. https://doi.org/10.1016/j.qref.2020.07.002

Sari, N. K., \& Widaninggar, N. (2018). Efisiensi Bank dalam Kelompok BUKU 4 di Indonesia: Pendekatan Data Envelopment Analysis. AFRE (Accounting and Financial Review), 1(2), 86-92. https://doi.org/ 10.26905/afr.v1i2.2409

Sari, N.K. dan Astuti, D.D. (2015). Faktor yang Mempengaruhi Manajemen Laba pada Sektor Perbankan Indonesia. Journal of Business and Banking. STIE Perbanas: Surabaya.

Sari, N.K., Turjono, E., dan Widaninggar, N. (2017). Penerapan IFRS dalam Praktik Manajemen Laba pada Bank Pemerintahan Indonesia. Jurnal Riset Akuntansi dan Bisnis: Airlangga. 2(2): 239-251.

Siladjaja, M., \& Anwar, Y. (2019). The impact of earning management on market earnings value: the causal study on the level of accruals. The Accounting Journal of Binaniaga, 4(2), 9. https://doi.org/ 10.33062/ajb.v4i2.338

Smith, D. D., \& Pennathur, A. K. (2019). Signaling Versus Free Cash Flow Theory: What Does Earnings Management Reveal About Dividend Initiation? Journal of Accounting, Auditing and Finance, 34(2), 284-308. https://doi.org/10.1177/0148558X1772405 1

Sulistyanto, S. (2014). Manajemen Laba: Teori dan Model Empiris. Jakarta: PT Gramedia. Sutikno, F., Wahidahwati, dan Asyik, N.F. (2012). Pengaruh Corporate Governance dan Ukuran Perusahaan terhadap Manajemen Laba di Industri Perbankan Indonesia. Jurnal Ilmu \& Riset Akuntansil. 3, (10).

Swastika, D. L.T. (2013). Corporate Governance, Firm Size, and Earnings Management: Evidence in Indonesia Stock Exchange. IOSR Journal of Business and Management. 14 (4): $77-82$

Ugbede, U., Lizam, M. and Kaseri, A. (2013). Corporate Governance and Earning Management: Emperical Evidence from Malaysian and Nigerian Banks. Asian Journal of Management Sciences \& Education. 2 (4): 121.

Weerathunga, P. R., Xiaofang, C., \& Sameera, T. K. G. (2020). Heterogeneity in Earning Management of Listed Companies Following International Financial Reporting Standards Convergence: a Developing Country Experiences. International Journal of Economics and Financial Issues, 10(1), 101-108. https://doi.org/10.32479/ijefi.8872 